\title{
ON SOME WALDENSIAN MSS PRESERVED IN THE LIBRARY OF TRINITY COLLEGE, DUBLIN.
}

THE literature of the Vaudois or Waldenses ${ }^{1}$ has been transmitted to us in some twenty-four MSS ${ }^{2}$, preserved at Cambridge, Carpentras, Dijon, Dublin, Geneva, Grenoble, and Zürich. The collection at Trinity College, Dublin, is the largest and by no means the least interesting. It comprises nine volumes. Of these, seven were carefully described by Todd. $^{3}$ An eighth was unearthed by Abbott, ${ }^{4}$ who published a very brief account of it in the course of which he expressed surprise that Todd should have passed it over. All these MSS date apparently from the late fifteenth or early sixteenth century.

It has been my good fortune to bring to light a ninth, and curiously enough much the most ancient of all the Dublin collection, for it can be with certainty dated between the years 1376 and 1400 . I shall commence with a detailed description of this MS.

I. MS A. 6. 10. In Abbott's Catalogue ${ }^{5}$ this MS bears the number 269, and is thus described: 'I. Tractatus contra Peccata varia. 2. Expositio Orat. Dominicae (Hispanice).' It is not easy to see how Abbott could have fallen into the error of describing this MS as Spanish. ${ }^{6}$ It is a small parchment volume consisting of 80 unnumbered folios measuring $x_{3}$ by 9 centimetres, written in single columns with ${ }_{4}$ lines to the page. There are a number of large red ornamental capitals, sometimes adorned with patches of yellow, and in two cases (ff. $3 a$, $78 a$ ) inlaid with gold. Some Latin headings in red in the second treatise. A few faint notes in the margins in a modern hand. The writing is beautifully clear and regular. It is well known that the

1 For general accounts see Herzog Die romanischen Waldenser, Halle, $18_{53}$; Montet Histoire litteraire des Vaudois du Piemont, Paris, 1885 ; and the excellent article by $\mathrm{H}$. Bohmer entitled 'Waldenser' in Hauck's Realencyklopadie für protestantische Theologie (Bd. xx, $3^{\circ}$ Aufl., 1908, pp. 799-840).

2 I am, of course, referring here solely to MSS written in the Vaudois dialect, a dialect of Provençal which has been specially studied by Gruzmacher in Archiv für das Studium der neueren Sprachen und Literaturen, xvi, 1854, pp. 369-407 ; Jahrbuch fur romanische und englische Literatur, iv, 1862, pp. 372-402, and by Barth Romanische Forschungen, vii, 1893, pp. 293-330.

s The Books of the Vaudois, London, $186_{5}$, pp. I-58.

4 Hermathena viii, 1892, pp. 204-206.

5 Catalogue of the MSS in the Library of Trinity College, Dublin, 1900, p. 40.

6 On this point see Todd Books, p. 2 I 3 note.

VOL. XVIII. 


\section{I78 THE JOURNAL OF THEOLOGICAL STUDIES}

Vaudois MSS are extremely difficult to date, ${ }^{1}$ so that it is fortunate for us that on the last folios of our MS the scribe has drawn up a Paschal Table, which commences with the year 1376 and continues to 1400 . The volume was thus certainly written before 1400 , and may with every probability be assigned to the year 1376 . It is thus one of the most ancient of the Waldensian MSS at present known to exist. ${ }^{2}$ The hand is not unlike that of the Cambridge MS $\mathrm{B}^{3}$ Abbreviations are not common. I have noted the following :-

$\overline{\mathrm{a}}=a n ;$ ai $=$ aico $;$ bati $=$ batismo $; \cdot \mathrm{C} \cdot=\operatorname{Car} ; \mathrm{o}=\mathrm{com} ; \mathrm{Zc}=$ et cetera ; enaí = enaisi ; $\mathrm{f} .=$ filh $; \cdot \mathrm{M} \cdot=$ Mas; mey $=$ meyre ; mìs $=$ mensis; mō = modo; n⿳亠丷厂 $=$ nostre; $\overrightarrow{\mathbf{P}}=$ Paul; $\mathrm{p}=$ per $; \mathrm{p} \tilde{\mathrm{p}}=$ propheta; $\overline{\mathrm{q}}$ or $\mathrm{q}_{3}=q u e ; \stackrel{\mathrm{q}}{\mathrm{q}}=q u i ; \sim$ above a vowel $=r$, thus segnõ $=$ segnor; $\overline{\mathrm{S}}$ or $\mathrm{s} .=$ Sant $; \mathrm{sc} \overline{\mathrm{t}}=$ sanct $; \tilde{\mathrm{t}}=$ tur $; \mathrm{X}=$ Christ $;$ Yerề $=$

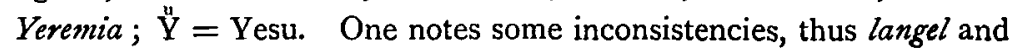
l'apostol, l'archa, d'aquest, so and aico.

f. I $a$ : Blank.

f. I $b$ : Some signatures in a seventeenth-century hand, illegible.

f. $2 a$ : More scribbles and the old press-marks A. 68 ; FFF. 5 ; A. I. 36 ; A. 46 .

f. $2 b$ : Blank.

ff. $3^{a-25} a$ : Without title. An exposition of the doctrines of the Waldensian Church in eleven chapters : Al nom del paire e del filh $\mathrm{e}$ del sant sperit nos volem recontar alcun testimoni de las sanctas scrituras per donar entendre e conoiser la gleisa de dio. La cal gleisa non es de peiras ni de fusta ni de nenguna cosa faita de man. Car scrit es al fait dels apostols "que lo aocessine non ista en cosa faita de man. Mas aquesta sancta gleisa es aiostament $\left[3^{b}\right]$ de fidels e de sant homes en la cal Yesu Christ ista e istara entro a la fin del segle.... [ [13a] Mas contra aquestas cosas la gleisa malignant romana di e aferma que hom deo iurar e di que dio iure e langel. Mas per tot ço si ille ben iureron non deuem nos iurar. Car a dio ni a langel non era dona ley ni comandament de non iurar.... [ $\left.\mathrm{r}_{3} b\right]$ Aico es manifest que per la gleisa malignant son fait plus de cent milia esperiurament... . [ [ $\left.{ }_{7} a\right]$ Aquesta gleisa sufre las persegacions e tribulacions e martiris per lo nom de Christ.... [18a] Nota en cal maniera totas aquestas parolas de Christ son contrarias a la gleisa maligna ${ }^{B}$ romana. Car ela non es

1 Cf. Berger in Romania xviii, 1889 , p. 377.

2 The most ancient appears to be the Vaudois Bıble at Carpentras, which is assigned by Berger (loc. ct., pp. $378,4^{16}$ ) to the fourteenth century.

8 A facsimile of B may be seen in the frontispiece of Montet's edition of La Noble Legon (Paris, 1888). The writing of our MS is larger and more regular. It resembles none of the specimens given by Gilly Romaunt Version of the Gospel of St John, London, $\mathrm{J}_{4} 8$.

- Acts xvil 24.

S Sic cod. 
persegua per ben ni per iusticia que ela haya en si. Mas per contrari ela persegh e aoci tot hom que no ${ }^{1}$ uol consentir a li sio peccat e a las soas faituras. Ela non fugis de cita en cita; mas segnoriza las citas e los borcs e las prouincias e se sey en grandeça en la ponpa d'aquest mont e es temuda dels reys e dels emperadors e dels aotres barons.... [ 18 b] Mas contra de ço li pastor de la gleisa romana non se uergognan de dire que ille son las fedas e li agnel de Christ e dizon que la gleisa de Christ que es perseguda de lor son li lop.... [25a, it ends] Donc tot hom que non es batiza d'aquest batism non es salf. Aico tuit aquille que eran de fora l'archa foron negat al diluuy. Car el $\mathrm{di}^{2} \mathrm{de}$ senblant forma uos fay salf lo batism et cetera.

Suficiat modo de batismo.

f. $25 b$ : Some scribbles in a seventeenth-century (?) hand.

ff. $26 a-77 a$ : A lengthy exposition of the Pater Noster. The first folio-between 25 and 26 -has been torn out, leaving only a fragment of a large red initial.... Aisi com el mostra per Yeremia propheta dizent, ${ }^{8}$ veuos yo los amenarei de la terra de aquilon e los aiostarei de las derrieranas de la terra; en plor uenran e en preyeras los remenaray. $E^{4}$ derreco cant li $\mathbf{L x X}$ an comenceran esser complit dis yo uisitarei $\mathrm{e}$ suscitarei sobre uos la mia bona parola que yo uos remene en aqst $^{5} \mathrm{loc}$, $\mathrm{e}^{6}$ apelares mi e andares e orares e yo uos eisaodirei; uos querres $\mathrm{mi}$ e trobares e yo remenarei la uostra caitiuetat, $[26 b]$ e uos aiostarai de totas las genz e de tot los locs als cals yo uos descatei ço dis lo segnor. ... [77 $a$, it ends] Aico l'apostol dis als hebr., ${ }^{7}$ e que el desliores aquelos li cal per la temor de la mort eran encolpat per tota lor uita a la seruitut. Gracia sia ab tuit li fidel que son en Yesu Christ. Amen.

f. $77 b:$ A few modern scribbles.

ff. $78 a-79 a$ : Sancta gleisa seruis a dio ab temor aisi com dis Sant Paul apostol, ${ }^{8}$ ab temor e ab tremolament obras la uostra salu. E per ço sancta gleisa cre als ditz de Dauid propheta. Car el dis, ${ }^{9}$ serues a dio en temor... [ [79a, it ends] Aico dis Sant Paul, ${ }^{10}$ ara nos sem desligat de la ley de peccat e de mort en la cal nos eram destengu et cetera. Enaisi dio nos ha afranqui per Yesu Christ nostre segnor.

ff. 79 $b-80 a:$ A Paschal Table ${ }^{11}$ written entirely in red in the same hand as the rest of the volume: Sequitur mensis pascalis. Miccclxxvi die xiiii Aprilis. Mccclxxvii die xxix Marcii ... Mัsccc die xxvii Marcii.

Sic cod.

- Ibid. xxix ro.

7 Heb. is 15 .

10 Rom. vii 6, viii 2 .

11 The figures do not always agree with those given in the Table in Nicolas Chronology of History, 1833, p. 61 .
2 I Pet. iil 21.

Sic cod.

- Phil. ii I2.
Ierem. xxxi 8, 9 .

Ierem. xxix I 2, 13, 14.

- Ps. ii II. 
f. $80 b$ : Blank.

As far as $I \cdot a m$ aware the tracts contained in this volume do not occur in any of the Waldensian MSS hitherto described. ${ }^{1}$

II. MS A. 6. 2 (No. 267 in the printed Catalogue). This MS was very briefly described by Abbott. ${ }^{2}$ It is a small paper volume measur. ing $\mathrm{r}_{4}$ by $10 \mathrm{~cm}$., written in single columns with from 26 to 33 lines to the page. There are 422 folios. An old hand has numbered ff. 8-42 I as $\cdot 1-409$. This numeration being inaccurate ${ }^{3}$ has not been here followed. Titles and initials are in red. The volume was written, apparently by several scribes, about the year $\times_{520}$. There are some marginal notes in what looks like a seventeenth-century hand. This MS was once in the possession of Jean-Paul Perrin, ${ }^{4}$ who published three of the tracts contained in it. ${ }^{5}$

f. I $a$ : Blank.

ff. $1 b-7 b$ : A Calendar, the January page of which was transferred ${ }^{6}$ from MS C. 5.22 in 1897 (note on commencing fly-leaf). On f. $7 b$ is a Table to find Easter with the Sunday Letters for the Cycle of 28 years. Opposite the letters $g . a$. for Leap Year is a date in red ink which has been tampered with. It was originally $\mathbf{I}_{520}$ (which agrees with the Sunday Letters), but has been altered into I I 20. Whether Perrin was the author of this deception or not it is impossible to say.

ff. $8 a-3$ I $a$ : Pecca. Lo es de saber che cosa sia pecca. . . A treatise on the seven deadly $\operatorname{sins}^{7}$ with their respective remedies, i.e. Superbia, Enuidia, Ira, Acidia, Auaricia, Golicia, Luxuria.

ff. $3^{\text {r } b-49 a}$ : Pecca de lenga. ${ }^{8}$ Motas cosas son las cals deorian more l'ome. . . .

f. $49 a-49 b$ : De la tauerna. ${ }^{9}$ La tauerna es fontana de pecca e scola del diauol....

1 I have not succeeded in tracing the provenance of this MS. It cannot be identified with any of the volumes in Perrin's possession (Histoire des Vaudois, Geneva, 1618, pp. 57-59). All the other Vaudois volumes at Dublin figure in Perrin's list (cf. Berger, Romania xviii p. 390).

2 Hermathena viii, $189^{2}$, pp 204-206.

3 Thus f. 343 is marked $33^{8}$.

4 He mentions it in these terms in his list: 'un livre intitule Antechrist avec plusieurs Sermons et un traité contre les pechés et des remèdes ' (Hist. des Vaudois, p. 57).

5 In a somewhat inaccurate manner.

- Todd (Books p. 22) in his description of C. 5.22 had noticed that 'the first leaf, the inside page of which contains the month of January, is a duplicate, and appears to have belonged to some other MS.'

${ }^{-7}$ There is another copy in MS C. 5. 22, ff. I $18 a-139 b$ (Todd Books p. 26).

Another copy in C. 5. 22, ff. $94 b-118 a$ (Todd, p. 26).

- Other copies in C. 5.22, f. $297 b$, and C. 5. 26, f. $68 b$ (Todd, pp. 39, 60). It has been printed by Perrin Histoire des Chrestiens Albigeois, Geneva, 1618, pp. $238-240$. 
f. $49^{b-53} b: \cdot$ Del bal. ${ }^{1} \quad$ Lo bal es la prosession del diauol. . . .

ff. $53^{b-54} b$ : A Sermon: Alcun non po seruir a duy segnor.... (Cf. Matt. vi 24.)

f. 55 : Blank.

ff. $56 a-350 a$ : $\dot{A}$ series of sermons on the Epistles and Gospels for the whole year : $O$ frayres sabent aquest temp.... (C. $5.22, f .3^{8}{ }_{5} b$, - Todd, p. 4r.)

ff. $350 b-357 b$ : Blank.

ff. $35^{8} a-377 b$ : Vergenas. Quon lo nostre segnor Yesu Christ era al mont cum li seo deciple. ...

ff. $377^{b-389} b$ : Qual cosa sia Antichrist. ${ }^{2}$ Antichrist es falseta de dapnacion eterna cuberta de specia de la uerita e de la iusticia de Christ. ... .

ff. $390 a-396 a$ : Sermon de la fena caninea laqual uenc a Yesu. . . .

ff. $396 a-403 a$ : Beneuranczas. Mas Yhesu ${ }^{3}$ vesent las compagnias monte al mont. . . .

ff. $403 b-404 b$ : No title: Adonca li iust ystaren en grant fortalecza encontra a quilh li qual angusti eron lor e a quilh li cal. . . . (Wisd. $v \mathrm{r}$ )

f. $405 a$ : Blank.

f. $405 b$ : Scribbles in a seventeenth-century (?) hand.

ff. $406 a-42$ r $b$ : Sermon de usura. Luc. ${ }^{4} \mathrm{Vn}$, home era ric et cetera. Aquest home ric sona maiorment ...

f. 422 : Blank.

III. MS C. 5.21 (No. $26 \mathrm{I}$ of the Catalogue). This volume was accurately described by Todd, ${ }^{5}$ since whose time it has been made the subject of much investigation. $^{6}$ It may be assigned to the end of the fifteenth or to the early sixteenth century. The principal contents are the Waldensian Poems ${ }^{7}$ and Physiologus. ${ }^{8}$

1 Printed, with the omission of a few lines, from this copy by Perrin (pp. 240 249). Other copies in C. 5. 22, ff. $292 a-297 b$, and C. 5. 26, ff. $65^{b-68 b}$ (Todd, pp. 39, 59).

2 Printed from this MS by Perrin (pp 253-295).

${ }^{s}$ The MS here has $Y h^{\prime} u$. Elsewhere it has $\stackrel{\sim}{Y}$, which $I$ have expanded into Yesu.

1 Lk. xvi I9.

- s Books, pp. 43-46. Todd's suggestion that it may have been written by the same scribe who wrote MS. C. 5.22 does not seem probable.

- Montet Hist. litt. p. 8 ; Balma Les poèmes Vaudors d'après le manuscrit C. 5. 21 de Trinily College, Dublin, pp. 3-7 (Extratt du Bulletin d'Histoire Vaudoise, No. 24, pp. 55 sqq., Torre Pellice, Juin 1906).

7 These poems are probably as old as the fourteenth century, cf. Stımming (ap. Grober Grundnss der romanischen Philologie, Bd. ii, Abt. 2, 1897, p. 52).

${ }^{8}$ Cf. Stimming loc, cit. pp. 68-69. 
The most celebrated of these poems, La Nobla Leyczon, was edited by Montet ${ }^{1}$ with a collation of this MS, and a facsimile of its script. The collation is carefully done. In verse 479 the MS has honor and not honors as given by the editor.

The remaining poems, Novel Confort, L'Avangeli de li quatre Semencz, La Barca, Payre Eternal, Lo Despreçi del Mont, Novel Sermon, and the piece entitled Oraf̧on, were published from this MS by Giovanni Balma. ${ }^{2}$ The transcript employed by him was by no means perfect, thus :-

Novel Confort, v. 6 pigricia $M S$, prigricia $E d$.

$L a$ Barca, 7 villecza $M S$, vilecza $E d . ; 27$ orten superbis $M S$, or te ensuperbis ${ }^{3} E d$.

Payre Eternal, 5 siencia $M S$, sciencia $E d$.

Novel Sermon, $\mathbf{5} 57$ the reading is certainly sec and not ser.

On ff. $49 a-70 a$ of this MS occurs the Vaudois Physiologus, which has been edited by Alfons Mayer, ${ }^{4}$ who believed this to be the only copy in existence, ${ }^{5}$ but there is another at Cambridge in the volume known as A (MS DD. 15. 29, ff. $17-48$ ), dating from the end of the fifteenth century. As this latter copy had been signalled many years ago by Bradshaw, ${ }^{6}$ and extracts from it printed by Montet, ${ }^{7}$ Mayer's ignorance seems inexcusable. The translation itself is assigned by the editor ${ }^{8}$ to the fourteenth century.

On comparing the printed text with our MS I found that Mayer's transcript was grossly inaccurate.

The following collation of the first fourteen chapters ${ }^{9}$ (Ed. pp. $396-$ 402) will fully demonstrate this :-

$396^{24}$ la $M S$, las $E d$. (twice); ${ }^{29}$ di $M S$, dit $E d$.; ${ }^{30} \mathrm{e} M S$, et $E d$.;

1 La Noble Legon, Paris, 1888, cf. pp. 2, 77-80. See also Appel Provenealische Chrestomathie, $3^{\circ}$ Aufl., 1907 , p. $1^{6}$; Emilio Tron L'epoca della composizione della Nobla Leigon (Bull. Hist. Vaud. 2 I, 1906, p. 32). The Geneva copy of this poem was'edited separately by Apfelstedt (Arch.f.d.Stud.d. neze. Spracken $u_{;}$Lit.1xii, 1879, pp. 273-288).

2 loc. cit. supra. There is as yet no critical edition of these poems. The Geneva copy (MS No. 207, middle of cent. 15) has been diplomatically reproduced by Friedrich Apfelstedt (Zetsschrift für romanische Philologre, Iv, 1880, pp. 330-346, $521-541$ ), a scholar whose career was cut short on January 5,1882 , at the early age of 23. He had just published a valuable study of the Lotharingian Psalter (Altfranzösısche Bibliothek, Bd. iv, Heilbronn, I881).

$s$ This is the reading of the Geneva MS (Apfelstedt, loc. cit. p. 331).

- Romanische Forschungen v, 1890, pp. 392-418.

- Ibzd. p. 394. 6 ap. Todd Books p. 216.

7 Histoure pp. 4-5, 220-225; cf. also Berger (Romana xviii p. 422).

loc. at. p. 395.

- Collation of the rest will follow in a future number. 
"conoissan $M S$, conissar $E d$. ; ${ }^{36}$ natura de l'ome es $M S$, natura es $E d$. ; ${ }^{37}$ degnetas $M S$, degnatas $E d$.; $397^{7}$ enayma ${ }^{1} M S$, eneyma $E d$.; ${ }^{7}$ psalmista ${ }^{2} M S$, salmista $E d . ;{ }^{8}$ gloria $M S$, glesia $E d . ;{ }^{10} \operatorname{degnetas} M S$, degnatas $E d . ;{ }^{18}$ enayma $M S$, eneyma $E d . ;{ }^{24}$ daquienant $M S$, dequienant $E d . ;{ }^{31}$ al solelh [ço es a dio e an natura al fuoc] $M S$, bracketed words omitted in $E d . ;{ }^{35}$ Enayma dis $M S$, Enayme di $E d . ;{ }^{36}$ emblanqueçi $M S$, emblanqueci $E d$.; $39^{8}{ }^{1}$ de $M S$, di $E d$.; ${ }^{7}$ reffuda $M S$, reffusa $E d$.; ${ }^{10}$ pauçin $M S$, paucin $E d . ;{ }^{17}$ dis $M S$, di $E d . ;{ }^{22}$ ilh $M S$, il $E d . ;{ }^{23}$ cun la mayre [enaysi que cun las lors alas fiero li uolh de la mayre] $M S$, bracketed words omitted in $E d$. ; ${ }^{23}$ auci $M S$, aucir $E d . ;{ }^{30}$ acer $M S$, aci $E d . ;{ }^{97}$ cenres [e d'aquela cenre es fait verm] e $M S$, the words in brackets omitted in Ed., the editor actually stating in a footnote, 'Hier fehlt, dass aus der Asche ein Wurm hervorgieng.' $399^{2}$ començan $M S$, comença $E d . ;{ }^{9}$ la $M S$, lo $E d$. ; ${ }^{10}$ merevilhos $M S$, mervilhos $E d$.; ${ }^{11}$ en Dio $M S$, Dio $E d . ;{ }^{17}$ quilh desiran de $M S$, qu'il desira se de $E d . ;{ }^{28}$ cagier $M S$, cagie $E d . ;{ }^{29}$ de quella $M S$, d'aquella $E d$. ; ${ }^{30}$ moiorment $M S$, maiorment $E d . ;{ }^{30}$ que dormir $M S$, qu'adormir $E d . ;{ }^{32}$ diāol ${ }^{3} M S$, diabol $E d$, and so throughout; ${ }^{36}$ tant maiorment [canta plus fort. E quant lo giorn s'apropia tant maiorment] s'acoita $M S$, bracketed words omitted in Ed. ; ${ }^{78}$ devotament $M S$, devotement $E d$.; $400{ }^{4} \mathrm{~d}$ is $M S$, di $E d . ;{ }^{9}$ nos nurissa $M S$, nurissa $E d$. ; ${ }^{10}$ segot $M S$, segont $E d$. ; ${ }^{13}$ per 3 veç $M S$, 3 veç $E d$.; ${ }^{14}$ qu'el cante $M S$, qu'il cante $E d$.; ${ }^{15}$ que el cante $M S$, qu'il cante $E d$.; ${ }^{15}$ quel lauue $M S$, que lauue $E d . ;{ }^{17}$ aurare $M S$, glorificare $E d . ;{ }^{17}$ aurar $M S$, glorificar $E d . ;{ }^{18}$ preyeras $M S$, preyras $E d . ;{ }^{18}$ eixauçias $M S$, eixaucias $E d . ;{ }^{19}$ e enay $M S$, Enaysi $E d$.; ${ }^{19}$ denant [quel cante ço es denant] que l'ome $M S$, bracketed words omitted in $E d$.; ${ }^{24}$ pauçin $M S$, paucin $E d$. ; ${ }^{25}$ vootor $M S$, votor $E d . ;{ }^{26,}{ }^{27}$ pauçin $M S$, paucin $E d$. (three times); ${ }^{29}$ mas $M S$, ma $E d . ;{ }^{30}$ annarey $M S$, anarey $E d$. ; $401^{2}$ payron $M S$, payren $E d . ;{ }^{10}$ conoisson $M S$, connoisson $E d . ;{ }^{12}$ graveça $M S$, graveza $E d . ;{ }^{15}$ gloria $M S$, glesia $E d . ;{ }^{15}$ celestia $M S$, celestial $E d . ;{ }^{17} N o$ title in $M S$, Del pic in $E d$. ; ${ }^{18}$ caua $M S$, caue $E d$; ${ }^{10}$ incz $M S$, inz $E a$.; ${ }^{21}$ oleua $M S$, enleva $E d . ;{ }^{29}$ diaol $M S$, diavol $E d . ;{ }^{23}$ stopare $M S$, stopera $E d . ;{ }^{23}$ de annar $M S$, d'annar $E d . ;{ }^{26}$ de retornar $M S$, retornar $E d$; ${ }^{30}$ ilh $M S$, il $E d$. ; $402{ }^{4}$ la nostra $M S$, l'umana $E d$.; ${ }^{\circ}$ compagnun $M S$, compaignun $E d . ;{ }^{8}$ čtia $M S$, castia ${ }^{4} E d$.; ${ }^{8}$ alcun non $M S$, alcun $E d$.; ${ }^{11}$ De perdiç $M S$, De la perdiç $E d$. ; ${ }^{14}$ reconoisson $M S$, reconnoisson $E d$.;

1 The MS has enay, an abbreviation found in all the later Vaudois MSS, and hitherto expanded as enayma by all editors. It has been suggested to read it enayst coma (cf. Berger Romania xviii p. $358 \mathrm{n}$.).

2 The MS has $\bar{p} s$.

8 This should be expanded diauol. At $402^{24}$ the MS has in full diouol where the Ed. reads diavol. At ${ }_{401}{ }^{23}$ the MS has diäl and the Ed. diavol.

4his is probably the correct expansion. 
${ }^{22}$ l'epervier $M S$, l'espervier $E d$. ; ${ }^{24}$ diovol $M S$, diavol $E d$. ; ${ }^{27}$ voutor $M S$, voutour $E d$.

It may be added that in the very last line of the work there are two mistakes, $4{ }^{1} 8^{96}$ albre $M S$, abre $E d$., and septanatz $M S$, sethanas $E d .^{1}$

M. Esposito.

\section{THE SOURCES OF SEDULIUS SCOTTUS' COL- LECTANEUM ON THE EPISTLES OF ST PAUL.}

IT may be doubted whether the importance of the ninth century either from the literary or from the palaeographical point of view has been sufficiently realized. It is the earliest century from which an abundant supply of Latin manuscripts has survived, and it is the earliest century which can shew any appreciable number of authors' autographs, or copies contemporary with those autographs. As a result it is also the earliest century for which we can reconstruct texts of faultless accuracy. Apart from the desirability of such reconstruction for its own sake, the ninth century was a great age of compilation from earlier sources of the fourth, fifth, sixth, and other centuries, some of which are otherwise lost, and all of which have fresh light thrown on their transmission by such compilations. From a palaeographical point of view, also, surely the right way to start solving the well-known difficulty of distinguishing ninth- and tenth-century writing would be to examine ninth- and tenth-century copies of ninth- and tenth-century works, whose date of composition is known. It would be very useful if some one would give us a series of ninth- and tenth-century facsimiles of this kind : nor would the work take particularly long. These remarks are suggested by such cases as Zmaragdus' Expositio Libri Comitis, whose sources were considered in an earlier number of the Journal, ${ }^{2}$ and also by Sedulius Scottus' Collectaneum on the Epistles of St Paul.

Sedulius Scottus, whose period and sphere of activity were the middle of the ninth century and Liege and the Rhine country, compiled, among other works, a set of notes on the Epistles of St Paul. From an old Fulda MS of this compilation, which has since disappeared, Johannes Sichardus printed the first edition at Basle in $\mathbf{I}_{528 .}{ }^{3}$ From

- A most thorough investigation of the language of the Poems and Physiologus was published by A. Barth (Romanusche Forschungen vii, 1893, pp. 293-330). The author knew nothing of the Cambridge MS of the Physiologus, and in view of the inaccuracy of Mayer's edition his work will require careful revision.

${ }^{2}$ Vol. ix (1907-rgo8), pp. 584-597.

s See especially P. Lehmann, Iohannes Sichardus und die von ihm benutzten Biblotheken-Handschriften (Munich I9I I), pp. 54 ff, I 20. 